\title{
The Effect of Focused Group Discussion to Enhance Students' Understanding on Premarital Sexual Behavior Risks
}

\author{
(Keefektifan Teknik Focus Group Discussion untuk Meningkatkan Pemahaman Resiko Perilaku \\ Seksual Pranikah Siswa)
}

\author{
Annisa Arrumaisyah Daulay*, Syawaluddin Nasution \\ Department of Islamic Guidance and Counseling, Faculty Da'wah and Communication, Universitas Islam Negeri Sumatera \\ Utara, William Iskandar St. 5 Ps. V, Deli Serdang 20371, North Sumatera, Indonesia \\ *corresponding author, e-mail: annisaarrumaisyahdaulay@uinsu.ac.id
}

Article received: June $16^{\text {th }} 2020$; revised: August 29 $9^{\text {th }} 2020$; accepted: October $19^{\text {th }} 2020$

\begin{abstract}
This study investigates the effectiveness of information service using a focus group discussion technique to improve students' understanding on the risks of premarital sexual behavior. It used a quantitative experiment method with one group pretest-posttest design, while its 30 subjects were selected using purposive sampling. The data analysis process was carried out using a t-test. The research results indicate improved students' understanding of the risks of premarital sexual behavior after they join information service with focus group discussion technique. Therefore, focus group discussion is effective to enhance students' understanding of premarital sexual behavior risks.
\end{abstract}

Keywords: information service; focus group discussion technique; premarital sexual behavior risks

\begin{abstract}
Abstrak: Penelitian ini bertujuan untuk mengetahui keefektifan layanan informasi teknik focus group discussion untuk meningkatkan pemahaman resiko perilaku seksual pranikah siswa. Penelitian kuantitatif eksperimen ini menggunakan desain one group pretest posttest. Teknik pengambilan sampel menggunakan teknik purposive sampling. Sampel penelitian sebanyak 30 orang siswa. Teknik analisis data menggunakan uji beda (uji t). Hasil penelitian menunjukkan terdapat kenaikan skor pemahaman siswa tentang resiko perilaku seksual pranikah setelah diberi layanan informasi teknik focus group discussion. Dapat disimpulkan layanan informasi teknik focus group discussion efektif dalam meningkatkan pemahaman siswa tentang resiko perilaku seksual pranikah.
\end{abstract}

Kata kunci: layanan informasi; teknik focus group discussion; resiko perilaku seksual pranikah 


\section{INTRODUCTION}

During high school time, students experience a transformation from childhood to adulthood or known as adolescence. The adolescence period ranges occur between 15-18 years old (Monks, Knoers, \& Haditono, 2002). During this period, teenagers frequently encounter identity crises; thus, they are dominated by curiosity (Hurlock, 1980). Besides, the development in this period is not only on their psychic but also in their physical (Lee et al., 2014). Significant physical changes are discovered in their sexual organ development which goes to the perfect function. Consequently, they become more sensitive and require substantial knowledge of premarital sexual behavior. Unfortunately, most high school students are categorized as teenagers who mostly find that information from the wrong source. Consequently, they do not obtain a thorough understanding. Students prefer to ask their friends rather than their parents, teacher, or experts in that field. According to Indonesia Demography and Health Survey (SDKI), $45 \%$ of students attain sexual behavior-related information from their friends, $6.8 \%$ find it from their parents, $8.7 \%$ get it from health workers, and $12.8 \%$ students obtain it from their teachers (Badan Pusat Statistik, 2013). It shows that students like to tell their sexual behavior to their friends. However, the information in sexual behavior obtained from their friends may lead to distorted understanding and negative behavior.

In addition, technological advancement also brings easy access to news related to sexual behavior. The uncomplicated access to social media and the internet complements students' curiosity. A study carried out by Polling Indonesia and the Indonesian Internet Service Providers Association (APJII) in 2018 shows that $64.8 \%$ of Indonesian access the Internet (APJII, 2018). Meanwhile, the majority of those users come from 15-19 years old teenagers or senior high school students (Kasyfi, 2019). This finding significantly affects students' transformation. Their information source can positively or negatively impact their life pattern, ethics, values, and morality. As for the fact, their obtained information mostly carries a negative effect and encourages students to commit premarital sexual behavior. Research has confirmed the significant effect of internet usage on premarital sexual behavior (Indrijati, 2017; Hakim \& Raj, 2017). Teenagers' great curiosity makes them feel no need of being anxious.

Communication is essential to build up parents and children relationship (Wamoyi, Fenwick, Urassa, Zaba, \& Stones, 2010). The lack of communication between parents and children provokes teenagers to feel free. Parents' inability to communicate with their children causes conflict that affects their children sexual behavior. The incorrect understanding of premarital sexual behavior occurs due to the absence of supervision from the proper person so that teenagers neglect the risks (Mayangsari, 2015).

The risks of committing premarital sexual behavior for teenagers range from a phycological perspective, such as being ashamed, stress, or even depressed, and physiologically, such as unwed pregnancy, rejection from their environment, or even get infected with HIV AIDS (Sarwono, 2012). Further, this behavior can also result in the infection of sexually transmitted diseases (STDs) and unwanted pregnancy (Azinar, 2013). In the end, premarital sexual behavior mostly leads teenagers to do an abortion without considering its side effects. The World Health Organization (WHO) data reveals that around two million abortion cases happen in Indonesia, every year, while 30\% of those cases are committed by teenagers. Additionally, abortion can result in death. Research and survey conducted by Worldometer identify that there had been 41.9 million death from abortion in 2018 (Simorangkir, 2019). Besides, the other risks possibly taken by teenagers are being a dropout and isolated from their peers. Unconsciously, premarital sexual behavior will not end and its risks endanger the future generation.

It is essential for teenagers to know and understand the risks of premarital sex. Other than parents and teachers, the school counselor also responsible to give students information about the risks of premarital sexual behavior through the information service. This service is an activity that improves an individual's comprehension of various topics for a purpose and plan. The specific aims of this service are connected to the function of guidance and counseling service, namely the function of understanding. This counseling function helps to improve an individual's limited knowledge to be used to prevent problems and resolve the problems they have faced (Amti \& Prayitno, 2008). The knowledge of premarital sex risks obtained from information service can be the crucial fundamental for students' development in the sex education context. It indicates that students can better filter the attained information, better.

This research adopted the focus group discussion technique. Focus group discussion facilitates an exploration of one specific issue by a group of individuals focusing on their activities to form a mutual agreement (Kitzinger, 1994). Their activities involve delivering ideas, responding to each other 
questions, and commenting on the experience related to a specific social topic defined in that group. Additionally, the discussed issue within the focus group discussion aims to comprehend approaches that form a group of people's behavior and attitude or to investigate perception, knowledge, and explanation on a general social issue that carries no threat to particular people (Lehoux, Poland, \& Daudelin, 2006). Besides, this technique also helps the process of decision making, belief-taking, expression-making, understanding a new behavior or terms used by the people related to the discussed topic (Paramita \& Kristiana, 2013).

The information obtained through focus group discussion is more affluent and informative since it involved direct interaction among the participant. By using the information service using the focus group discussion technique, the students have the opportunity to freely discuss and deliver their ideas on the discussed topic with guidance from the facilitator. In other words, it effectively enhances students' confidence (Fitriani, 2019). Focus group discussion method has been proven to improve elementary students' learning motivation on the social science subject (Aswad, 2019). Besides, the focus group discussion in the cooperative learning model also prepares students' critical thinking and mathematical communication skills in Islamic Junior High School (MTs) Muhammadiyah 1 Malang (Syaifullah, 2018). Aside from comprehension, focus group discussion also develops students' ability to properly communicate.

Studies on premarital sexual behavior have been massively carried out. The findings from Rahmawati (2011) shows that visual media increases comprehension of premarital sexual behavior risks on junior high school students. Additionally, teenagers' knowledge and attitude related to premarital sex can be enhanced using counseling activity in adolescent healthcare service program (PKPR) (Rahayu, 2013). Group counseling services using discussion techniques have been observed to carry effects on students' premarital sexual behavior (Damayanti, Anni, \& Mugiarso, 2016). Research conducted by Rachmayanie (2017) describes premarital sex as one of the problems encountered by teenagers. Further, a study carried out by Novianti (2018) identifies that communication, information, and education becomes some of the factors that inhibit premarital sexual behavior. A group guidance service on the sex education program for ten graders of Private Vocational High School Yayasan Pendidikan Delisha Tandem Hilir II has been successfully conducted due to the provision of proper facilities (Isdhayanti, 2019). Even if premarital sexual behavior has been extensively investigated, but focus group discussion has never been adopted to liberate students to interact with their peers. Discussion technique aids a group to deeply investigate a particular topic. This study examines the effectiveness of the information service using a focus group discussion to enhance students' premarital sexual risks understanding.

\section{METHOD}

This research used one group pretest-posttest design experiment (Creswell \& Creswell, 2017). The information service was given using the focus group discussion technique, while the subjects' initial condition had been discovered before the treatment. A pretest was administered before the treatment using the sexual behavior risk scale. After that, they joined the information service using the focus group discussion technique which was ended with a posttest (after the treatment).

This research population was 203 eleventh grade students in State Senior High School 1 Kutacane who had filled the premarital sexual behavior risk comprehension scale. Later, the subjects were selected through a purposive sampling technique with criteria of low premarital sexual behavior risk understanding. According to the scale deployment, 30 students were selected as the research sample. This selection was also equipped with observation, along with school counselor recommendation considering several criteria. The criteria include students who like to be together with their partner, have had a romantic relationship, and like to intrude with their opposite sex.

The information service through the focus group discussion was given five times with discussion materials in the form of ice breaking and presentation of papers and videos related to premarital sexual behavior and its risks. The students were divided into five groups randomly, with six students in each group. They were given a pretest, followed by an information service using focus group discussion which involved three stages of preparation, discussion, and closing stages. During the preparation phase, students obtained an explanation of the purpose and objectives, along with the material they were going to discuss. Meanwhile, in the discussion stage, the facilitator provided material related to premarital 
sexual behavior and its risks that would be discussed in each group. In the closing phase, each group presented their discussion result, while the facilitator gave the conclusion of the discussed topic. The provided materials sequentially were the importance of sexual education for teenagers, factors that provoke premarital sexual behavior, the risks of premarital sexual behavior, life values, and me and my future. After that, students were given a posttest as an evaluation of the activities.

To identify the effectiveness of information service implementation using focus group discussion to enhance students' understanding of premarital sexual behavior risks, the results of pretest and posttest were compared. The analysis process was completed using a t-test. The instrument used in this study was the premarital sexual behavior scale which its validity and reliability had been tested. Based on the correlation coefficient calculation, the $r_{\text {count }}=0.453$ on the significant level of $\alpha=5 \%$, then $r_{\text {table }}=0.361$. Consequently, the $r_{\text {count }}$ was greater than $r_{\text {table }}(0,453>0,361)$. Further, an estimation using the Alpha formula resulted in $\mathrm{r} 11=1.024$, which was categorized as a high category in the correlation index.

\section{RESULTS}

Information service using focus group discussion has been provided to subjects with the initial condition that had been identified. The subjects were given a pretest using the premarital sexual risks understanding scale. Later, they were treated with a focus group discussion technique with the material in each of the five meetings and ended with a posttest. The posttest results signify that the subjects attain higher scores. The detailed comparison of the pretest and posttest scores of 30 students through a statistic test is presented in Table 1. The results indicate the minimum score from the pretest and posttest are 59 and 74, respectively. The score increased by 15 points. Simultaneously, the pretest and posttest maximum scores are 91 and 101, respectively, which also improves by ten points. Meanwhile, the average scores before and after the treatment are 72.96 and 84.3, respectively, which also accelerates by 11.34 points.

The hypothesis test was carried out using t-test. If the probability $<0.05$, then $\mathrm{H}_{0}$ is rejected and $\mathrm{H}_{1}$ is accepted. The estimation result of $\mathrm{t}_{\text {table }}$ on N-1 $=30-1=29$ and real level of $\alpha=0.05$ is $\mathrm{t}_{\text {table }}=2.045$ and $t_{\text {count }}=9.793$. Thus, $9.793>2.045\left(t_{\text {count }}>t_{\text {table }}\right)$, showing a difference before and after the provision of information service through the focus group discussion technique. Therefore, information service using focus group discussion is effective to enhance students' comprehension of premarital sexual behavior.

Table 1. Pretest and Posttest Scores of the Experiment Group

\begin{tabular}{ccccc}
\hline No & Subject & Pretest Score & Posttest Score & Improvement \\
\hline 1 & MA & 59 & 82 & 23 \\
2 & LR & 62 & 83 & 21 \\
3 & SP & 64 & 82 & 18 \\
4 & PY & 64 & 84 & 20 \\
5 & BT & 64 & 80 & 16 \\
6 & AA & 65 & 87 & 22 \\
7 & RA & 66 & 83 & 17 \\
8 & ZD & 66 & 84 & 18 \\
9 & MH & 67 & 74 & 7 \\
10 & ED & 68 & 82 & 14 \\
11 & FS & 69 & 83 & 14 \\
12 & JM & 71 & 82 & 11 \\
13 & HR & 71 & 82 & 11 \\
14 & BE & 71 & 84 & 13 \\
15 & RA & 71 & 85 & 14 \\
16 & RP & 72 & 80 & 8 \\
17 & JS & 72 & 78 & 6 \\
18 & IH & 74 & 86 & \\
\hline & & & & 12 \\
\hline
\end{tabular}


Table 1. (continued) Pretest and Posttest Scores of the Experiment Group

\begin{tabular}{ccccc}
\hline No & Subject & Pretest Score & Posttest Score & Improvement \\
\hline 19 & NV & 75 & 88 & 13 \\
20 & FA & 76 & 85 & 9 \\
21 & RNI & 76 & 80 & 4 \\
22 & JO & 76 & 83 & 7 \\
23 & SA & 78 & 90 & 12 \\
24 & SD & 79 & 81 & 2 \\
25 & MA & 79 & 87 & 8 \\
26 & DP & 84 & 86 & 2 \\
27 & FN & 84 & 87 & 3 \\
28 & JW & 86 & 88 & 2 \\
29 & RN & 89 & 93 & 4 \\
30 & NY & 91 & 101 & 10 \\
\multicolumn{7}{c}{ Mean } & 72.96 & 84.3 & 11.34 \\
\hline
\end{tabular}

\section{DISCUSSION}

This study aims to discover the effectiveness of information service using the focus group discussion technique to increase senior high school students' understanding of premarital sexual behavior risks. Statistically, students' comprehension of premarital sexual behavior risks has been accelerated after the implementation of information service using the focus group discussion technique, shown by the difference observed before and after the treatment. Through an individual observation on the pretest and posttest scores, some students are found to have no significant transformation. Consequently, this focus group discussion technique carries different effects for each individual.

Parallel to a study carried out by Mahfudzoh (2020) using GenreKit media that the overall students' understanding of sexual behavior risk has been accelerated, even if some students only experience insignificant improvement. Research by Hendrik and Ratini (2018) using audio-visual media has also increased students' comprehension of premarital sexual behavior. However, the comprehension level of each individual remains varied due to many factors. In this information service using the focus group discussion technique, the great number of participants becomes a challenge for the facilitator to control the discussion process. In the implementation process, focus group discussion requires welltrained facilitators and a conducive environment to realize optimum interaction between the participants (Lambert \& Loiselle, 2008).

Focus group discussion is one of the strategies that involve social interaction between the individuals during the discussion (Afiyanti, 2008). In addition to its effectiveness, focus group discussion also offers room for students to openly interact with their peers in discussing the premarital sexual behavior risks which are not commonly discussed with their parents. Their peers have a role in male and female students' great premarital sexual behavior (Suparmi \& Isfandari, 2016). Therefore, the school counselor can optimize the role of peers through the classroom learning process or other school activities.

Education, one of the means that provide information and knowledge for students, is expected to carry solutions to resolve social issues faced by each student. School counselor have a number of services that can enhance students' understanding of premarital sexual behavior risks, one of them is information service using focus group discussion technique.

Information service specifically becomes an integrated part of a lesson in the guidance and counseling. It discusses things related to daily life and aims to give knowledge, understanding, and information to help students to choose effective and meaningful attitude. It is linear to the results of this research that information service is effective to enhance students' comprehension of premarital sexual behavior. There are various reasons why information services are essential to be conducted, (1) individual have to learn various knowledge related to their environment to solve the educational, sociocultural, and occupational issue; and (2) it enables individual to decide their life direction and choose the right decision (Amti \& Prayitno, 2008). 
The focus group discussion technique presents targeted discussion lead by a facilitator. This technique is effective to enhance understanding of premarital sexual behavior risks since it gives indepth information related to the discussed topic so that the topic can be defined and explained (Afiyanti, 2008). It is relevant to the number of focus group discussion characteristics. First, it aims to explore and attain various explanations related to the topic. Second, its facilitators act as the moderator that inductively guide, listen, observe, and analyze. Third, it facilitates a focus discussion on a specific topic or issue. Fourth, the discussed topic is based on the participants' need that has been selected by the facilitator. Fifth, the emerge question can be developed and adjusted with the topic that has been coherently arranged so that the participant can easily understand it.

The information service using the focus group discussion technique also gives opportunities for students to discuss with their peers in a group. They can identify the risks of premarital sexual behavior from different perspectives and comprehend the idea from each participants' perspective (Hennink, 2013). The obtained understanding aids students to develop following their developmental tasks. That developmental tasks include accepting their physical transformation, properly and effectively using their physical function, and intellectually develop to hold a role in their society (Hurlock, 1980).

As its purpose, information service presents different knowledge and understanding that help students to know themselves better, plan and develop their life pattern as a student, family member, and society member (Nursalim, 2002). Information service has been massively investigated to improves students' comprehension. This information service has been identified to enhance students' understanding of the impacts of free sex behavior (Nurhalimah, 2013). In that research, students only obtain information from their school counselor. Besides, information service using discussion technique has also increased understanding of underage marriage effects (Kabang \& Trisnowati, 2018). That study uses a discussion method with no specific technique. Meanwhile, the focus group discussion technique implemented in this study aims to give an opportunity for students to openly interact with their peers and exchange information related to the topic given by the facilitator.

Therefore, the information service using the focus group discussion technique in this study trains students to properly communicate and filter their attained information. Students with an adequate understanding of premarital sexual behavior risks tend to demonstrate a positive attitude and avoid premarital sex behavior (Mayangsari, 2015). Consequently, the obtained information is expected to help students to properly adapt to their environment, make a decision, being positive and dynamic, select meaningful activities, and can correctly actualize themselves.

\section{CONCLUSION}

Information service using focus group discussion has been effectively enhanced students' understanding of premarital sexual behavior risks. However, this technique requires a conducive environment to realize optimum interaction between the participant. This finding can be one of the alternative methods carried out by the counselor to facilitate students to explore a topic or issue. As a result, students can attain knowledge and understanding, particularly on premarital sexual behavior and its risks. The implementation of the focus group discussion technique carries an opportunity for students to have a meaningful and effective discussion with their peers, learn to properly communicate, become more critical in accepting information, and can develop following their developmental tasks. Future studies are suggested to involve a control group to better identify the difference and use time-series design.

\section{REFERENCES}

Afiyanti, Y. (2008). Focus group discussion (diskusi kelompok terfokus) sebagai metode pengumpulan data penelitian kualitatif. Jurnal Keperawatan Indonesia, 12(1), 58-62.

Amti, E. \& Prayitno, P. (2008). Dasar-dasar bimbingan dan konseling. Rineka Cipta.

APJII. (2018). Profil pengguna internet Indonesia 2018.

Aswad, H. (2019). Efektivitas pelaksanaan metode diskusi kelompok terpusat (focus group discussion) terhadap motivasi belajar IPS murid kelas V SD Negeri II Bone-Bone Kota Baubau. PERNIK: Jurnal Pendidikan Anak Usia Dini, 2(01), 28-55. 
Azinar, M. (2013). Perilaku seksual pranikah berisiko terhadap kehamilan tidak diinginkan. KEMAS: Jurnal Kesehatan Masyarakat, 8(2). 153-160

Badan Pusat Statistik. (2013). Survei demografi dan kesehatan Indonesia 2012. Jakarta: Kementrian Kesehatan RI.

Creswell, J. W., \& Creswell, J. D. (2017). Research design: Qualitative, quantitative, and mixed methods approaches. Sage publications.

Damayanti, M., Anni, C. T., \& Mugiarso, H. (2016). Layanan informasi berbantuan media audio-visual untuk meningkatkan minat berwirausaha siswa. Indonesian Journal of Guidance and Counseling: Theory and Application, 5(1), 39-44.

Fitriani, E., \& Azhar, A. (2019). Layanan informasi berbasis focus group discussion (FGD) dalam meningkatkan kepercayaan diri siswa. Analitika: Jurnal Magister Psikologi UMA, 11(2), 82-87.

Hakim, S. N., \& Raj, A. A. (2017). Dampak kecanduan internet (internet addiction) pada remaja. In Prosiding Temu Ilmiah Nasional X Ikatan Psikologi Perkembangan Indonesia (Vol. 1, pp. 280-284).

Hendrik, H., \& Ratini, R. (2018). Meningkatkan pemahaman resiko perilaku seksual pra nikah melalui layanan informasi dengan media audio visual siswa SMA Negeri 2 Mempawah. JBKI (Jurnal Bimbingan Konseling Indonesia), 3(2), 31-35.

Hennink, M. M. (2013). Focus group discussions. Oxford University Press.

Hurlock, E. B. (1980). Psikologi perkembangan: Suatu pendekatan sepanjang rentang kehidupan. Jakarta: Gramedia.

Indrijati, H. (2017). Penggunaan internet dan perilaku seksual pranikah remaja. In Prosiding Temu Ilmiah Nasional X Ikatan Psikologi Perkembangan Indonesia (Vol. 1, pp. 44-51).

Isdhayanti, A. (2019). Upaya guru BK dalam menanamkan pendidikan seks siswa melalui layanan bimbingan kelompok di kelas X SMK Swasta Yayasan Pendidikan Delisha Tandem Hilir II (Doctoral dissertation, Universitas Islam Negeri Sumatera Utara).

Kabang, M., \& Trisnowati, E. (2018). Pemahaman tentang akibat pernikahan di bawah umur melalui layanan informasi dengan teknik diskusi. Jurnal Bimbingan dan Konseling Ar-Rahman, 4(2), 55-60.

Kasyfi, H. (2019). Jumlah pengguna internet di Indonesia tembus 171 juta jiwa. Retrieved from https://tekno. kompas.com

Kitzinger, J. (1994). The methodology of focus groups: the importance of interaction between research participants. Sociology of health \& illness, 16(1), 103-121.

Lambert, S. D., \& Loiselle, C. G. (2008). Combining individual interviews and focus groups to enhance data richness. Journal of advanced nursing, 62(2), 228-237.

Lee, F. S., Heimer, H., Giedd, J. N., Lein, E. S., Šestan, N., Weinberger, D. R., \& Casey, B. J. (2014). Adolescent mental health—opportunity and obligation. Science, 346(6209), 547-549.

Lehoux, P., Poland, B., \& Daudelin, G. (2006). Focus group research and "the patient's view". Social science \& medicine, 63(8), 2091-2104.

Mahfudzoh, D. (2020). Peningkatan pemahaman siswa tentang resiko perilaku seksual pranikah melalui layanan bimbingan klasikal dengan media genre kit. Empati-Jurnal Bimbingan dan Konseling, 7(1), 23-35.

Mayangsari, D. (2015). Hubungan tingkat pengetahuan dan sikap remaja dengan perilaku tentang seksual pranikah. Jurnal Kesehatan Masyarakat, 43-53.

Monks, F. J., Knoers, A. M. P., \& Haditono, S. R. (2002). Psikologi perkembangan: pengantar dalam berbagai bagiannya. Yogyakarta: Gajah Mada University Press.

Novianti, R. (2018). Komunikasi, informasi dan edukasi (KIE) meningkatkan pengetahuan tentang pencegahan perilaku seksual pranikah pada remaja. Jurnal Keperawatan dan Kebidanan, 8(1). 33-43

Nurhalimah, S. (2013). Penerapan layanan informasi bimbingan pribadi untuk meningkatkan pemahaman siswa mengenai dampak perilaku seks bebas di SMAN 1 Sugihwaras Bojonegoro. Jurnal BK Unesa, 4(1).

Nursalim, M. (2002). Layanan bimbingan dan konseling. Surabaya: Unesa University Press.

Paramita, A., \& Kristiana, L. (2013). Teknik focus group discussion dalam penelitian kualitatif. Buletin Penelitian Sistem Kesehatan, 16(2). 117-127

Rachmayanie, R. (2017). Seks pra nikah sebagai problematika remaja sekolah menengah. In Proceeding Seminar dan Lokakarya Nasional Bimbingan dan Konseling 2017 (Vol. 1, pp. 248-263).

Rahayu, N. (2013). Pengaruh kegiatan penyuluhan dalam pelayanan kesehatan peduli remaja (PKPR) terhadap pengetahuan dan sikap remaja tentang seks pranikah di SMAN 1 Lubuk Dalam Kabupaten Siak Sri Indrapura tahun 2013. 
Rahmawati, S. (2011). Layanan informasi dengan menggunakan media visual di kelas VIII SMP Negeri 4 Purbalingga.

Sarwono, W. S. (2012). Psikologi remaja: Definisi remaja. Jakarta: Raja Grafindo Persada.

Simorangkir, R. F. (2019). Aborsi penyebab kematian terbesar, Indonesia butuhkan UU prostitusi. Retrieved November 19, 2019, from https://www.kompasiana.com

Suparmi, S., \& Isfandari, S. (2016). Peran teman sebaya terhadap perilaku seksual pranikah pada remaja laki-laki dan perempuan di Indonesia. Indonesian Bulletin of Health Research, 44(2), 139-146.

Syaifullah, S. (2018). Penggunaan model pembelajaran kooperatif tipe focus group discussion pada kemampuan berpikir kritis dan komunikasi matematis siswa di MTs Muhammadiyah 1 Malang (Doctoral dissertation, University of Muhammadiyah Malang).

Wamoyi, J., Fenwick, A., Urassa, M., Zaba, B., \& Stones, W. (2010). Parent-child communication about sexual and reproductive health in rural Tanzania: Implications for young people's sexual health interventions. Reproductive Health, 7(1), 1-18. 